\title{
Location and locatum verbs revisited: Evidence from aspect and quantification
}

\author{
Víctor Acedo-Matellán \\ Universidade do Minho \& Centre de Lingüística \\ Teòrica, Universitat Autònoma de Barcelona \\ victoracedoma@ilch.uminho.pt
}

Cristina Real-Puigdollers

Centre de Lingüística Teòrica, Universitat Autònoma de Barcelona

cristina.real.puigdollers@uab.cat

\begin{abstract}
In this paper we claim that location and locatum verbs are grammatically different, contrary to some recent analyses (Mateu 2001; 2008; Harley 2005). While aspectual tests are known to distinguish both classes, we adduce new evidence from degree quantification tests pointing in the same direction. In particular, location verbs seem to be change-of-state verbs, and locatum verbs behave rather like degree achievements and unergative verbs of variable telicity. We claim that these differences must be accounted for in the syntactic representation of locative verbs. While location verbs involve an abstract bounded path, articulated through the combination of a Path preposition and a Place preposition, locatum verbs involve an abstract predicative preposition that allows for degree quantification of the root and contextually determined (a)telicity.
\end{abstract}

Keywords: locative verbs; inner aspect; verbal quantification; argument structure; event structure

\section{Introduction}

This work proposes an analysis of denominal locative verbs, which involve the location of an entity with respect to another entity. Locative verbs are usually divided into two classes, location and locatum verbs, depending on their semantic interpretation: as shown in (1), while location verbs like Catalan embotellar 'bottle' denote the location where the direct object has moved onto, locatum verbs like Catalan ensellar 'saddle', denote the element that has been moved onto the location expressed by the direct object: $^{1}$

${ }^{1}$ Observe that both embotellar and ensellar feature a prefix of prepositional origin (en-/em- < Latin in-). As the present discussion will show, the presence of this pre- 
(cf. botella 'bottle')

the Jan has in-bottle.PTCP the=water

'Jan has bottled the water.'

b. L'Elna ha en-sellat el cavall.

(cf. sella 'saddle')

the $=$ Elna has in-saddle.PTCP the horse

'Elna has saddled the horse.'

Location and locatum verbs have been treated either as two fundamentally different classes of verbs (Labelle 2000; Hale \& Keyser 1997, and subsequent works) or as grammatically non-distinct (Mateu 2001; 2002; 2008; Harley 2005). In this work, we propose that they are grammatically distinct classes, attending to their aspectual and quantificational properties.

With respect to the aspectual properties of locative verbs, we show that location verbs are always change-of-state verbs, irrespective of the root that they embed. This means that these verbs license a telic reading of the predicate, provided that the direct internal argument possesses the relevant boundedness properties (Verkuyl 1972; Krifka 1992; 1989; Borer 2005; MacDonald 2008). By contrast, locatum verbs are ambiguous between a telic and an atelic reading even when their internal argument is bounded. With respect to their quantificational properties, we show that locatum and location verbs show different interpretations when combined with degree modifiers. Building on these considerations, we claim that location verbs involve an abstract bounded path preposition and locatum verbs involve an abstract predicative preposition. Finally, we show that some locative verbs are ambiguous between a location and a locatum reading. We attribute this fact to the possibility of associating the same root to two different structures, which is possible within a neoconstructionist framework, as the one adopted here.

The paper is organized as follows. In section 2 we revise the most influential previous accounts of location and locatum verbs. In sections 3 and 4 we focus on the aspectual and quantificational properties of these verbs, respectively. In section 5 we propose to analyse the predicates headed by these verbs as involving different syntactic configurations. We draw conclusions in section 6 .

fix seems orthogonal to the location/locatum distinction. For discussion on prefixed location and locatum verbs in Catalan, see Acedo-Matellán (2006). For discussions on the same issue in other Romance languages see, among others, di Sciullo (1996, and subsequent works) on French and Italian, Kopecka (2006) on French and Bassani (2012) on Portuguese. 


\section{Review of previous proposals}

Locative verbs have attracted the attention of researchers from Clark \& Clark's (1979) seminal descriptive work on denominal verbs. In Pinker's (1989) and Jackendoff's (1990) approaches these verbs involve a semantic representation of caused motion containing an abstract noun which gives name to the verb. This noun is the located figure in the case of locatum verbs and the ground of the locative relation in the case of location verbs, as shown in the next representation of locatum butter and location pocket by Jackendoff $(1990,170)$ :

(2) a. CAUSE ([Thing $\alpha]$, [Event INCH [BE ([Thing BUTTER], [Place $([\mathrm{ON}([$ Thing $\beta])])]])]$

b. CAUSE $([$ Thing $\alpha],[$ Event GO $([([$ Thing $\beta],[$ Path TO $([$ Place IN $([$ Thing POCKET $])])])])]$

Labelle (2000) proposes to simplify these accounts by positing that in both location and locatum verbs the affected argument is the overt direct object, while the one encoded by the verbal root represents the final state undergone by the entity denoted by the object. The difference between locatum and location verbs is not structural, but resides in the type of preposition featured by either type of verb in their conceptual representation. Thus, while location verbs feature a locative, AT-type preposition, locatum verbs feature a WITH-type preposition. This is shown in the next semantic representations of the French locatum fleurir 'cover with flowers' and location entreposer 'store' in Labelle (1992):

(3) a. CAUSE $(x,[\operatorname{INCH}(\mathrm{WITH}$ fleur(s) $(y))])$

b. CAUSE $(x,[\operatorname{INCH}(\operatorname{AT}$ entrepot $(y))])$

Thus, the mapping between theta-roles and grammatical functions becomes homomorphic in Labelle's (1992) account. ${ }^{2}$ However, as pointed out by Mateu (2001), there is no morphological evidence that these verbs involve so many different semantic operators as proposed by Labelle. This analysis is closely paralleled by the l(exical)-syntactic one proposed by Hale and Keyser (1997, and subsequent works). For these authors, the l-syntactic configuration of both types of verbs is exactly the same. It involves a prepositional projection that takes the surface direct object as its specifier and the nominal root as its complement. In turn, this prepositional projection is the complement of a verbal head that verbalizes the whole structure (Hale \& Keyser 2002, 18):

\footnotetext{
${ }^{2}$ See Kiparsky (1997) for an analysis similar to that of Labelle's (1992).
} 
(4) a. [V V [P [DP the horse] [P (= central coincidence relation) saddle]]]

b. [V V [P [DP the book] [P (= terminal coincidence relation) shelve]]]

For these authors, the semantic difference between locatum and location verbs is non-configurational. It emerges from the fact that they involve different prepositions: a preposition of terminal coincidence in the case of location verbs and a preposition of central coincidence in the case of locatum verbs. In a nutshell, a central coincidence is that between a figure and a ground whose centres coincide, while a terminal coincidence is that between a figure and a ground whose edges coincide (Hale 1986). Unlike in Labelle's (1992) semantic approach, a number of diagnostic tests like participation in the middle construction and unavailability of the causative alternation are shown to derive from the configurational properties of the l-syntactic representations. Notably, however, neither Labelle's nor Hale and Keyser's analysis discusses the inner-aspectual and quantificational properties of these verbs.

Mateu $(2001 ; 2002 ; 2008)$ does take the inner-aspectual properties of locative verbs into account. In particular, Mateu (2001; 2002) claims that both location and locatum verbs are change-of-state verbs and that they respond in the same way to grammatical diagnostics assumed to detect the lexical encoding of a telicity-inducing transition (a terminus): middle formation, adjectival passive formation and allowance of object-hosted depictive secondary predicates. Thus, in contrast with Hale and Keyser's (1997) analysis, Mateu (2001; 2002) proposes that location and locatum verbs not only share the same structure, but they also feature the same preposition, namely, one of terminal coincidence, which is claimed to yield the change-of-state semantics characteristic of these predicates. Thus, location and locatum verbs would be undistinguishable, the difference becoming strictly non-grammatical, as shown in the next l-syntactic analysis of French locatum fleurir 'cover with flowers' and location entrepoter 'store' (Mateu 2001, 18):

(5) $\quad[\mathrm{V} \mathrm{V}$ [X [DP la tombe/la marchandise] [X fleur/entrepot]]]

$(\mathrm{X}=$ terminal coincidence relation $)$

Crucially, a different position is adopted in Mateu (2008). In this work he acknowledges the existence of atelic predicates headed by locative verbs like water. He proposes that location and locatum verbs that may head telic predicates, such as shelve or saddle, involve a preposition of terminal coincidence, while locatum verbs that are interpreted as atelic, such as water, involve a preposition of central coincidence: 
(6) a. [V V [P [DP the book/the horse] [P (=terminal coincidence) shelve/saddle]]]

b. [V V [P [DP the plants] [P (= central coincidence relation) water]]]

Mateu (2008) assumes therefore a grammatical, non-configurational difference that, however, does not coincide exactly with the location/locatum difference. This new position constitutes, therefore, a partial return to Labelle's (1992) and Hale and Keyser's (1997) types of analysis.

Harley (2005) adopts Mateu's (2001; 2002) proposal that locatum and location verbs are grammatically undistinguishable, since they involve exactly the same configuration with an abstract semantically inert preposition. Harley proposes that the differences in (a)telicity in locative verbs depend exclusively on the (un)boundedness of the nominal root that the verb is built on, the abstract preposition making no contribution to the computation of inner aspect. Thus, a bounded root like $\sqrt{\text { CORRAL yields }}$ corral, which may head telic predicates, while an unbounded root like

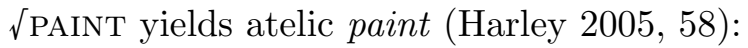

(7) $\int_{\mathrm{vP}}\left[\mathrm{DP}\right.$ Jill/Bill] $\int_{\mathrm{v}^{\prime}} \mathrm{v}[\mathrm{SC}[\mathrm{DP}$ the horse/the wall $\left.\left.][\mathrm{PP} \mathrm{P}[\sqrt{ } \mathrm{P} \sqrt{\mathrm{CORRAL}} / \sqrt{\mathrm{PAINT}}]]]\right]\right]$

Finally, MacDonald (2008, 95-96) shows that the aktionsart of location and locatum verbs is different. Specifically, while location verbs are uniformly interpreted as achievements, which this author derives within an l-syntactic theory of verb formation, some locatum verbs license an activity interpretation. Thus, the durative adverbial in the next example involving the locatum verb powder is compatible with a single event interpretation (op.cit., 109):

(8) Mary powdered her nose for ten minutes.

MacDonald proposes that location verbs enter the syntax with a feature able to induce telicity (his $\langle\mathrm{fe}\rangle$ feature), while locatum verbs such as powder, do not. We concur with the idea that locatum verbs are not structurally determined as involving a definite transition able to induce telicity. However, we will show in section 3 that locatum verbs such as powder or water may head telic or atelic predicates, which has to do, in our opinion, with the contextual construal of the root that they embed.

In this work we adopt an analysis where locatum and location verbs are grammatically distinct, in the spirit of Labelle (1992) and Hale \& Keyser (1997, and subsequent works). We base our analysis on the aspectual behaviour of these verbs, as done by other authors such as MacDonald (2008). However, we provide new evidence based on how these verbs respond to quantification. 


\section{The aspectual interpretation of locative verbs}

The empirical claim in this section is that locatum and location verbs are event-structurally different. Location verbs are grammatically specified as involving a definite transition. Thus, in MacDonald's (2008) terms they possess the relevant $\mathrm{E}$ (vent) $\mathrm{S}$ (tructure) property to be interpreted as telic predicates. Locatum verbs, on the other hand, are not grammatically specified as involving a definite transition. Whether they may head telic or atelic predicates depends on how their root is construed with respect to boundedness - and, of course, on the (un)boundedness of the direct internal argument. Since in this work we are not interested in this latter factor, let us first distinguish it more explicitly from the ES property.

We assume, following MacDonald (2008), that two essential factors must be differentiated in discussions of telicity (as grammatically represented, see section 5.1), at least for languages like English or Catalan: the abovementioned ES property and the $\mathrm{O}$ (bject) $\mathrm{T}(\mathrm{o}) \mathrm{E}$ (vent) mapping. The former is a property of the $\mathrm{vP}$ independent of the nature of the internal argument. It emerges from how the event is structured, i.e., if it has an endpoint or not. The latter is a property that depends on the nature of the internal argument (Verkuyl 1972; Krifka 1989). The OTE mapping is effective with predicates that posses the ES property of having an endpoint, like those headed by trencar 'break'. With these predicates, in languages like English or Catalan, a bounded (or quantity, in Borer's 2005 terms) internal argument NP induces a telic interpretation, while an unbounded internal argument NP induces an atelic interpretation, as shown, respectively, in the next examples:

(9) a. La Jana ha trencat l'ampolla en/\# durant dos segons.

the Jana has broken the=bottle in/for two seconds

'Jana has broken the bottle in two seconds.'

b. La Jana ha trencat vidre durant/ $/{ }^{*}$ en dos minuts.

the Jana has broken glass for/in two minutes

'Jana has broken glass for two minutes.'

With predicates that do not possess the relevant ES property, like those headed by empènyer 'push', the OTE mapping is not effective. With these predicates, therefore, the nature of the internal argument, i.e., whether it is bounded or not, does not bear on the inner aspect of the predicate, which is invariably atelic: 
(10) a. L'Elna ha empès la mula durant/" en deu minuts.

the $=$ Elna has pushed the mule for $/$ in ten minutes

'Elna has pushed the mule for ten minutes.'

b. L'Elna ha empès bestiar durant/ $/{ }^{\#}$ en deu minuts.

the=Elna has pushed livestock for/in ten minutes

'Elna has pushed livestock for ten minutes.'

As pointed out above, in this work we are not concerned with the OTE mapping. Rather, we are concerned with the ES property of locative verbs. In the examples provided in the remainder of the paper we will use bounded internal arguments, so that a predicate with the relevant telicity-inducing ES property will show as telic. At the same time, we will refer to such predicates as telic, tacitly assuming that their telicity depends also on the OTE mapping.

A second preliminary observation concerns the test involving durative adverbials such as for five minutes, probably the most widely used in detecting atelicity. We recall that predicates licensing a durative adverbial can be claimed to be atelic only if they are interpreted as involving a single event, specifically, a process temporally bounded by the durative adverbial itself (MacDonald 2008):

(11) Sue drank beer for hours.

Crucially, however, durative adverbials are licensed by telic predicates under three main interpretations. In the first interpretation, there is also a single event but the durative adverbial does not measure the span of any process, but that of a result state yielded by a telic eventuality (Binnick 1969, cited by Dowty 1979, 58; Kratzer 2000; MacDonald 2008):

(12) John caught a bear for ten minutes.

The sentence above is interpretable as 'the bear remained caught for ten minutes'. Accordingly, the adverbial for ten minutes can be claimed to be measuring the result state. The other two telic readings admitting a durative adverbial are what MacDonald (2008, 41-46) calls Sequence of Identical Events (SIE) interpretation and Sequence of Similar Events interpretation. As for the former, it involves examples such as the following one, with a singular bounded internal argument (op.cit., 41):

(13) The farmer dragged a log into the barn for an hour. 
In this example we understand that the farmer engaged in successive events of dragging the same log into the barn for an hour straight. As for the SSE reading, it emerges in telic predicates with a bare plural internal argument (ibid., 46):

(14) The girl ate cookies for an hour.

Here we can interpret a sequence of events consisting in the eating of each of an unbounded number of cookies.

Having made clear these readings, let us deal with the aspectual properties of location verbs. Mateu $(2001 ; 2002 ; 2008)$ claims that these verbs are telic. We note that this telicity is independent of whether a root is interpreted as bounded or unbounded, contrary to Harley's (2005) position. Thus, a verb such as Catalan engabiar 'cage', built on bounded gàbia 'cage' is fine with delimiting adverbials and does not admit a process interpretation when combined with a durative adverbial. It only allows a result state interpretation and a SIE interpretation (examples from Mateu 2001, 8):

(15) a. Ell en-gabià el seu ocell preferit en un minut. he in-caged the his bird favourite in one minute 'He caged his favourite bird in one minute.'

b. Ell en-gabià el seu ocell preferit durant un minut. he in-caged the his bird favourite for one minute 'He caged his favourite bird for one minute.'

Process, single-event interpretation: 区 Result state interpretation: $\square$ SIE interpretation: $\square$

Identical results are obtained for encapsar 'box', enlleixar 'shelve', embotellar 'bottle', empresonar 'imprison', acorralar 'corral', etc. Crucially, and against Harley (2005), the situation is the same with location verbs involving a root that could be considered mass-denoting, like enterrar 'bury', built on terra 'earth':

(16) Els pirates en-terraren el tresor durant tres dies.

the pirates in-earth.PST.3SG the treasure for three days

'The pirates buried the treasure for three days.'

Process, single-event interpretation: $\boldsymbol{\bigotimes}$

Result state interpretation: $\square$

SIE interpretation: $\square$ 
There are less location verbs based on mass roots than based on roots referring to bounded objects, but the ones we find behave in the same way: envinagrar 'put in vinegar' (which also licenses the locatum reading 'put vinegar on'), emmarar-se 'get into the sea', emboscar-se 'place in the woods'.

In contrast with the above scenario, the aspectual behaviour of locatum verbs seems to depend on how the root is construed: if it is construed as bounded, then the locatum verb behaves as telic. If it is construed as unbounded, the locatum verb behaves as atelic. For instance, the verb enfarinar 'put flour on' licenses an atelic process interpretation in the following example: ${ }^{3}$

(17) En Joan en-farinà el pastís durant deu segons. the Joan in-floured the cake for ten seconds

'Joan floured the cake for ten seconds.'

Process, single-event interpretation: $\square$

However, the same predicate is compatible with a reading in which there is a definite amount of flour being put onto the cake. In that case, the SIE interpretation - a series of events of putting a bounded amount of flour into the cake - and the interpretation in which the durative adverbial measures the final state of being covered with flour are possible, if pragmatically quite odd. Other verbs such as salar 'put salt onto', embetumar 'put shoe polish onto' or emmelar 'put honey onto' behave alike.

The situation is identical with locatum verbs involving roots related to bounded objects. So for instance minar 'lay mines on a field', related to bounded mina 'mine', admits an atelic, single-event interpretation if the amount of mines laid is unbounded:

(18) Els soldats minaren el camp durant un dia.

the soldiers mined the field for one day

'The soldiers mined the field for one day.'

Process, single-event interpretation: $\square$

${ }^{3}$ An anonymous reviewer claims that in this example with enfarinar 'flour' we get atelic behaviour because the extent of the cake can be construed as unbounded. We do not agree with this claim. Note that, according to all standard tests, the DP the cake counts as denoting a bounded entity. Thus, it is not cumulative (Krifka 1992; 1998; Kiparsky 1998), since any addition made to the cake impedes the denotation of the cake to apply, and it is also not divisive (Kiparsky 1998), since no fraction of the cake can be denoted by the cake (see also Borer 2005). 
And, again, in case a bounded quantity of mines is understood to be laid, the predicate may be telic. Identical behaviour to that of minar is shown by abalisar 'put buoys on' or embanderar 'put flags on'.

We note that the case of telic enfarinar, built on unbounded farina 'flour' and the case of atelic minar, built on bounded mina 'mine', are in contradiction with Harley's (2005) assumption that unbounded roots yield atelic predicates and bounded roots yield telic predicates. Although we agree with Harley (2005) that the telicity or atelicity of locatum verbs does not depend on their grammatical configuration, we disagree in her classifying roots as ontologically bounded or unbounded. Rather, the root is pretty free to be understood either as a bounded entity or an unbounded entity.

Finally, we point out a problem with Mateu's (2008) perspective on the aspectual properties of locative verbs that has to do with the status of location and telic locatum verbs. Mateu (2008) proposes that the only division within the locative class concerns the telic/atelic division, which clashes with the claim that locatum verbs may have an atelic interpretation and location verbs cannot - cf., in this sense, Harley's (1999) observation that location verbs seem to be telic, since "locations are bounded". The idea could be entertained that it is precisely the fact that the predicate is lexically bounded (by the presence of a preposition of terminal coincidence, for instance) what provides the verb with the location flavour. From this perspective, so-called telic locatum verbs like saddle would receive their locatum interpretation by virtue of encyclopaedic knowledge, their grammatical representation being exactly identical to telic verbs interpreted as location. However, this does not explain the fact that some telic locative verbs such as envinagrar, based on vinagre 'vinegar' or ensorrar, based on sorra 'sand', are ambiguous between a locatum and a location reading:

(19) La Jana en-vinagrà els cogombres en cinc minuts.

the Jana in-vinegar.PST.3SG the cucumbers in five minutes

'Jana \{seasoned the cucumbers with vinegar/put the cucumbers in vinegar\} in five minutes.'

This example has two telic readings: in the locatum reading Jana has seasoned the cucumbers with a bounded amount of vinegar, and that has taken her five minutes; in the location reading, Jana has put the cucumbers into some container full of vinegar, and that has taken her five minutes. Importantly, the difference between the location and the locatum reading can be brought to surface with the addition of adjuncts further specifying the locatum and location: while de-PPs may specify locatums, PPs based on locative prepositions may only specify locations: 
(20) a. La Jana en-vinagrà els cogombres de vinagre de poma.

the Jana in-vinegar.PST.3SG the cucumbers with vinegar of apple

'Jana seasoned the cucumbers with apple vinegar.'

Location reading: $\boldsymbol{\otimes}$

Locatum reading: $\square$

b. La Jana en-vinagrà els cogombres en pots de vidre.

the Jana in-vinegar.PST.3SG the cucumbers in jars of glass

'Jana put the cucumbers in vinegar, within glass jars.'

Location reading: $\square$

Locatum reading: $\mathbf{\square}$

This means that telicity does not determine the exclusion of the locatum reading, and that the locatum/location division is, after all, worth considering as grammatically real, as had been proposed by Labelle (1992) and Hale and Keyser (1997).

To sum up the results of this section, we have seen that while location verbs are uniformly telic, locatum verbs are telic or atelic depending on whether the root is construed as a bounded or an unbounded entity.

\section{Quantificational properties of locative verbs}

In this section we explore the quantificational properties of locative verbs. First, we review Bosque \& Masullo's (1998) approach to verbal quantification and propose an explicit account. Then we show the different readings of i-quantification with locative verbs and how they shed light on the structural properties of these predicates. Finally, we point out data that relate the inherent quantification and the aspectual properties of locative verbs.

Bosque and Masullo (1998) claim that there are five different types of verbal quantification, which are illustrated below with examples from Catalan (21a, b, d, e) and Spanish (21c). The different types of verbal quantification are obtained according to the different variable over which the quantifier can scope: quantification over an event variable (e-quantification), over a variable of time (d-quantification), over a covert argument (a-quantification), over any element within the VP (Unselective Binder quantification) and over the internal verbal predicate (inherent quantification):

(21) a. En Jan ha cantat molt aquesta cançó.

e(ventive)-quantification

the Jan has sung a_lot this song

'Jan has sung this song very often.' 
b. L'Elna ha dormit una mica.

d(urative)-quantification the=Elna has slept a little

'Elna has slept a little.'

c. Juan ha bebido mucho.

(Spanish) a(rgumental)-quantification Juan has drunk a_lot

'Juan has drunk a lot.'

d. La gent ha vist molt aquesta exposíció.

U(nslective) B(inder)-quant. people have seen a_lot this exhibition

'Many people have seen this exhibition.'

e. L'Elna estima molt el seu gat. i(nherent)-quantification the $=$ Elna loves a_lot her cat

'Elna loves her cat a lot.'

In this paper we focus on i-quantification readings, defined by Bosque and Massullo (1998, 19-20) as follows: the quantificational reading of a modifier that quantifies "over a component of the sub-lexical structure of the predicate, more specifically, the lowest predicate available in a lexical relational structure, in the sense of Hale \& Keyser (1991; 1993a; 1994a;b)". This type of reading is illustrated in the a-examples below; the b-examples are analytic counterparts:

(22) a. La ferida sagnava molt.

the wound bled a_lot

b. La ferida treia molta sang.

the wound produced lots_of blood

'The wound was bleeding a lot.'

(23) a. En Jan ha tardat molt.

the Jan has delayed a_lot

b. En Jan ha fet molt tard.

the Jan has made very late

'Jan is very late.'

Specifically, Bosque and Masullo (1998) propose that some denominal verbs allow for a quantificational open variable projected over the embedded noun. A degree modifier can bind this variable, producing the effect that the embedded noun is quantified. The next example illustrates their analysis of inherent-quantification (from op.cit., 34, ex. 42): 
(24) Sangrar bastante.

bleed.INF a_lot

'To bleed quite a lot.'

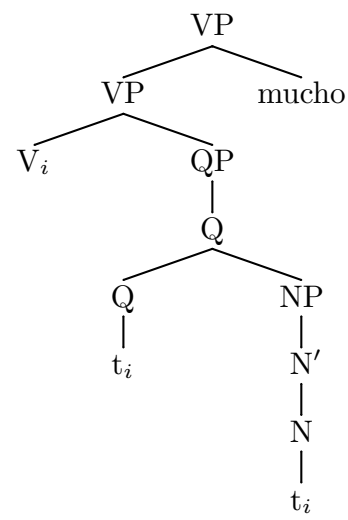

The five types of quantification defined in (21) can arguably be reduced to two: e-quantification and i-quantification. In this respect, we follow Gallego \& Irurtzun (2010), who show that a-quantification and i-quantification can be unified through the assumption that in both cases the quantifier has scope over an internal argument position. In addition, d-quantification and e-quantification can also be collapsed. In both cases, the degree quantifier scopes over an eventive variable, and d-quantification obtains if the event is aspectually durative and non-delimited, that is, in the case of activities and states. The case of UB-quantification illustrated in (21d) can be shown to boil down to a particular pragmatic interpretation of an e-quantification reading. The sentence in this example licenses the implicature that a lot of people have seen an exhibition on the basis of the assertion that people have very often seen that exhibition. Actually the UB-quantification interpretation can be cancelled without a contradiction, (25a), contrary to the interpretation licensed by properly quantified nominal expressions, (25b), or in other cases of verbal quantification $(25 \mathrm{c})$ :

(25) a. La gent ha vist molt aquesta exposíció the people have seen a_lot this exhibition

però l'ha vista poca gent.

but it=have seen few people

'People have seen this exhibition very often, but few people have seen it.' 
b. Molta gent ha vist aquesta exposíció

many people have seen this exhibition

\# però l' ha vista poca gent.

but it= have seen few people

"Many people have seen this exhibition, ${ }^{\#}$ but few people have seen it.'

c. Sangró mucho, ${ }^{\#}$ pero perdió poca sangre.

bled a lot but lost few blood

'He bled a lot, but he lost few blood.'

In conclusion, following Gallego \& Irurtzun (2010), we propose that all these five cases of verbal quantification boil down to scopal differences that are obtained when a modifier quantifies the vP: the modifier can take scope over and below v. These cases of verbal quantification, then, can be unified with other approaches to vP modification, as von Stechow's (1995; 1996) account of the different readings that arise with adverbs like English again or German wieder. In all these cases, the modifier can have scope over the inner structure of the verbal predicate. The analysis therefore accounts for different readings of degree modifiers in the verbal domain in purely structural terms. The degree quantifier is a modifier that can be adjoined above $\mathrm{v}$, where an eventive variable is introduced, and below v. In this respect we differ from Bosque \& Masullo (1998) and Gallego \& Irurtzun (2010), who claim that the semantic properties of the root always license the i-quantification reading. In our account, the root only affects i-quantification when it is immediately under the scope of the degree modifier.

Let us now review how locative verbs differ as to their behaviour regarding i-quantification. Locatum verbs that contain a root that denotes an entity interpretable as unbounded allow i-quantification. This is the case with both verbs denoting a mass entity, such as enfarinar 'flour' or salar 'salt', and verbs that denote a bounded entity usually used in an unbounded plurality, like minar 'lay mines onto':

(26) a. L'Elna ha en-farinat massa les mandonguilles. the=Elna has in-flour.PTCP too_much the meatballs 'Elna has put too much flour on the meatballs.'

b. L'Elna ha salat poc el rostit. the $=$ Elna has salt.PTCP little the roast 'Elna has put too little salt on the roast.' 
c. Els soldats minaren massa el camp.

the soldiers mine.PST.3PL too_much the field

'The soldiers have put too many mines in the field.'

In these examples the adverb is interpreted as quantifying the amount of flour, salt and mines, respectively, being employed in the course of the event.

Locatum verbs such as encaputxar 'hood', ensellar 'saddle' and emmanillar 'handcuff', do not allow i-quantification, since the roots they embed denote things that are usually used in a bounded fashion. Indeed, it is usually one hood, one saddle and a pair of handcuffs that are involved:

(27) a. "L'Elna ha en-caputxat massa la nena. the=Elna has in-hood.PTCP too_much the girl 'Elna has hooded the girl too much.'

b. "L'Elna ha en-sellat massa el cavall. the=Elna has in-saddle.PTCP too_much the horse 'Elna has saddled the horse too much.'

c. "L'Elna ha em-manillat massa en Jan. the=Elna has in-handcuff.PTCP too_much the Jan 'Elna has handcuffed Jan too much.'

Location verbs show a different pattern with respect to i-quantification. When the root denotes a bounded entity, disallowance of i-quantification is very clear, as can be observed in these examples containing the roots

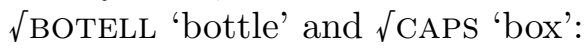

(28) a. \#En Jan ha em-botellat massa l'aigua.

the Jan has in-bottle.PTCP too_much the=water

'Jan has bottled the water too much.'

b. "En Jan ha en-capsat massa els llibres. the Jan has in-box.PTCP too_much the books 'Jan has boxed the books too much.'

With respect to location verbs embedding an unbounded root, there are some that disallow the i-quantification reading of the degree quantifier:

(29) \# En Jan ha envinagrat massa els cogombres. the Jan has in-vinegar.PTCP too_much the cucumbers

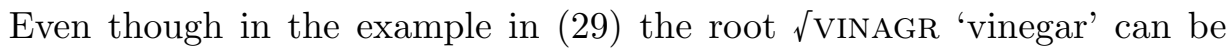
construed as denoting a mass, envinagrar in the location sense does not 
allow an inherent quantification reading. We claim that i-quantification is not possible in this case because even if the root can be construed as an unbounded entity, the root is interpreted as a location and not as a quantity of mass. Thus, the degree quantifier is not modifying the root but a location.

From these considerations one might conclude that locations are always bounded, and therefore, non i-quantifiable. However there seem to be some apparent exceptions. Thus, some location verbs embedding an unbounded root allow i-quantification readings. Verbs such as enterrar 'bury', emboscar-se 'go into the forest' or emmarar-se 'go into the sea', which contain roots related to mass entities such as terra 'earth', bosc 'forest' or mar 'sea', do allow i-quantification readings of the degree quantifier:

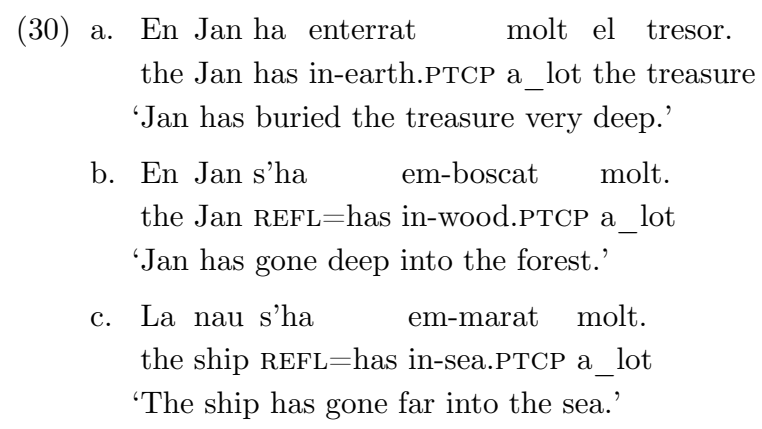

Even if these roots are usually interpreted as unbounded entities, it can be argued that they are quantifiable not because they are mass, but because they are construed as unbounded locations. If this is correct, the interpretation of the quantifier with location verbs is different from that with locatum verbs: while the adverbial quantifier takes scope over the entity denoted by the root in the latter case, it takes scope over an unbounded location in the former case. To justify this claim, we now adduce evidence from the realm of overt prepositions and their interaction with degree quantification.

Quantification of location verbs works similarly to quantification of prepositions like in or inside. These prepositions are usually treated as not allowing quantification by degree modifiers (Zwarts 1997). However, there are two counterexamples to this claim: adverbial modification such as in deep in the forest and measure phrase modification of inside when the ground denotes an unbounded location. Thus, when this preposition combines with grounds that are understood as not having limits, i.e., unbounded grounds, it can be understood as quantifiable. More precisely, according to Zwarts \& Winter $(2000,191)$, the possibility of modification 
of the preposition inside depends on whether the reference object itself is upward vector monotonic or not, in other words, if the reference object (the ground, in our terms) has an unbounded denotation. (Un)boundedness in this case does not refer to the mass/count distinction but to the existence or non-existence of limits in the conception of the object as a location. For instance, while DPs such as the house and the wall license a salient count interpretation, they behave as bounded and unbounded locations, respectively, in combination with inside. Accordingly, they behave differently with respect to degree modification (Zwarts \& Winter 2000):

(31) a. ${ }^{*} 10 \mathrm{~cm}$ inside the house

b. $10 \mathrm{~cm}$ inside the wall

Applying this reasoning to location verbs, quantification is possible if the root can denote an unbounded ground, such as terra 'earth', and impossible when it denotes a bounded ground, such as capsa 'box' (see 28b). As in the case of inside, the adverb quantifies over the location, not directly over the root. For example, the interpretation in (32) is that Jan buried the treasure too deep, too much inside the earth. Thus, in (32) the adverb is not quantifying the quantity of earth that has been used to bury the treasure. Quantification of the root understood as a mass is not obtained:

(32) En Jan ha en-terrat molt el tresor.

the Jan has in-earth.PTCP a_lot the treasure

'Jan has buried the treasure very deep.'

In sum, i-quantification in locatum and location verbs shows different scope properties. This conclusion goes against Bosque and Masullo's $(1998,50)$ claim that locatum and location verbs contrast with respect to i-quantification because the former always contain an unbounded nominal and the latter a bounded one. In the next section, we will clarify this statement when we propose our analysis of locative verbs. The different i-quantification readings of the degree modifier will depend on the nature of the complement of $\mathrm{v}$ as stated above.

Finally, we discuss the relationship between i-quantification and the facts related to aspectual interpretation that were presented in section 3 . This relation is different in location and locatum verbs. Thus, i-quantifiable locatum verbs like enfarinar 'flour' or minar 'mine' can receive a telic or an atelic reading, while non-i-quantifiable locatum verbs like ensellar 'saddle' can only be interpreted as telic: 
(33) a. L'Elna ha en-farinat les mandonguilles en/durant un minuts. the $=$ Elna has in-flour.PTCP the meatballs in/for some minutes 'Elna has floured the meatballs in/for some minutes.'

b. L'Elna ha en-sellat el cavall en $/{ }^{\#}$ durant uns minuts. the $=$ Elna has in-saddle.PTCP the horse in/for some minutes 'Elna has saddled the horse in/for some minutes.'

In the case of location verbs, on the contrary, (a)telicity does not depend on the construal of the root. Both i-quantifiable and non-i-quantifiable location verbs induce a telic interpretation of the event. Therefore, the bounded or unbounded construal of the location does not affect the boundedness of the event in the case of location verbs:

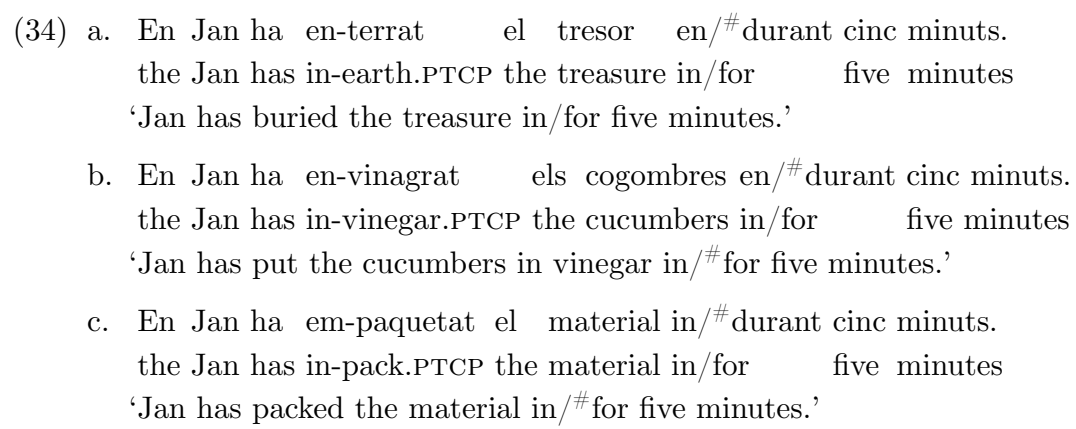

In conclusion, while locatum verbs can give rise to telic or atelic interpretations and the (un)bounded construal of the root is relevant for aspectual interpretation, location verbs can only give rise to telic interpretations, irrespective of the (un)bounded construal of location that they express. The question that remains is then: why does the construal of the root not affect the aspectual interpretation of the predicate in the case of location verbs? What is the relation between i-quantification and aspect? We answer these questions in the next section.

\section{An analysis of locative verbs}

In this section we propose an analysis of locatum and location verbs that aims at accounting for their aspectual and quantificational properties. We propose that location and locatum verbs are grammatically different: although they both embed a configuration of prepositional nature, the prepositions involved are different. The analysis is couched within a syntactic approach to argument structure and word-formation. Thus, with Hale \& 
Keyser $(1993 ; 2002)$ and the Distributed Morphology Framework (Halle \& Marantz 1993; Harley \& Noyer 1999; Marantz 2013; among others) we propose that the structural semantics and syntactic behaviour of words must be accounted for through the same syntactic mechanisms as those underlying the behaviour of phrases. Abstract hierarchical representations yielded by syntax are interpreted by the idiosyncratic morphophonology of each language to produce (prosodic) words. ${ }^{4}$ Importantly, we also endorse the fundamental idea of neo-constructionist frameworks (Marantz 1997; 2013; Borer 2005) that roots, as items containing exclusively conceptual information, can appear in different structures. The limit to this freedom is set by the compatibility between the descriptive content of the root and the structural semantics of the construction in which it is inserted.

\subsection{Two types of telicity}

In order to analyse the inner-aspectual properties of locative verbs, we must first make clearer our position with respect to the nature of telicity, expanding on what was pointed out at the beginning of section 3 . We propose that there are two possible sources for telicity: one that is of grammatical nature and one that is of non-grammatical (contextual) nature. Within a localist approach to aspect (Acedo-Matellán 2010), we claim that the former is implemented through the presence of a complex spatial prepositional projection, PathP, articulated through the abstract prepositions Path and Place. Place establishes a static relation between a figure and a ground. Path, merged on top, introduces the semantics of transition. This higher preposition pulls up the nearest DP in its c-command domain onto its specifier. If this DP is bounded, the entity denoted by the DP is interpreted as the measurer of the event (Tenny 1989; 1994), and by virtue of the OTE mapping gives rise to telicity: ${ }^{5}$

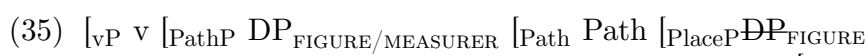

[Place Place DP/Root ${ }_{\text {GRound }}$ ]]I]

\footnotetext{
${ }^{4}$ In this work we are not concerned with these morphophonological mechanisms. For relevant discussion, see Hale and Keyser (2002); Acedo-Matellán (2010) or RealPuigdollers (2013).

${ }^{5}$ Here and in the rest of the syntactic representations we do not represent movement operations orthogonal to our purposes, such as the movement of the direct object to Spec-v or v-to-T movement.
} 
As for the non-grammatical source of telicity, we claim that when the PathPlace articulation is absent, contextual factors and world knowledge can induce a particular construal of the root in terms of boundedness, so that a root construed as bounded may induce telicity. One case of non-grammatically represented telicity is that allowed by unergative birthing verbs like foal:

(36) The mare foaled in two hours. (Harley 2005, 46) $[\mathrm{vP} \quad \mathrm{V} \sqrt{\mathrm{FOAL}}]$

In this example, the most felicitous way to construe the meaning of the

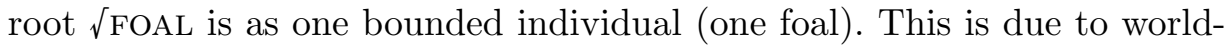
knowledge: mares usually give birth to one foal. By hypothesis, however, there is nothing in the structure of this predicate forcing a transition interpretation, that is, in our terms, no Path-Place configuration. Rather, these predicates involve, as proposed by Harley (2005) or Hale and Keyser (1993), a verbal head taking a non-relational element - a root, in our terminology, and that of Harley's. This is shown in the representation of (36). That the telicity of birthing verbs is not grammatically represented is suggested by the behaviour of these verbs in languages like Italian. In Italian, telic intransitive predicates usually take the BE auxiliary in the perfect tense. Thus, as shown in the next examples from Folli \& Harley $(2006,135)$, a verb like correre, which selects the HAVE auxiliary in the atelic unergative, interpretation, takes the BE auxiliary in telic unaccusative predicates:

(37) a. Gianni ha corso nel bosco $\left\{\right.$ per ore/ ${ }^{\#}$ in un minuto $\}$.

John has run in=the woods for hours/in one minute

'John has run in the woods for hours.'

b. Gianni é corso nel bosco $\left\{\right.$ in un minuto $/{ }^{\#}$ per ore $\}$.

John is run in=the woods in one minute/for hours

'John has run into the woods in one minute.'

Crucially, as pointed out by Mateu (2008), birthing verbs like figliare 'foal' take the HAVE auxiliary in the perfect, in spite of their telicity:

(38) La giumenta $\{$ ha figliato/*è figliata $\}$ in due ore.

(Mateu 2008)

the mare has foaled.M.SG/is foaled.F.SG in two hours

'The mare has foaled in two hours.'

Importantly, it should be recalled that, as was pointed out in section 3 , we are not claiming that roots are ontologically bounded or not, as does Harley (2005). Rather, roots can be construed as bounded or unbounded as 
dictated by world-knowledge and contextual reasons. In the case of foal, an atelic reading is grammatically possible, if aberrant for world-knowledge reasons: it would involve a mare giving birth to an unbounded plurality of foals.

\subsection{Location verbs as involving Path-Place configurations}

With this theoretical background in mind, let us first deal with the analysis of location verbs. As has been shown, location verbs involving a bounded internal argument are telic irrespectively of the kind of root that they contain (pace Harley 2005). In the present framework, this means that location verbs involve a Path-Place articulation giving rise to a definite transition interpretation. We illustrate with the verb enterrar 'bury':

(39) En-terrar els bulbs.

in-earth.INF the bulbs

'Bury the bulbs.'

[vP v [DP els bulbs] [PathP Path [PlaceP †DP els bulbst|Place' Place (= INSIDE) $\sqrt{T E R R}]$ ]]

An abstract Place preposition articulates the figure-ground relation between the direct internal argument (els bulbs 'the bulbs') and the root $(\sqrt{T E R R})$. The higher Path head introduces a transition, and effects the raising of the internal argument DP onto its specifier. Since this DP is bounded, the OTE mapping induces telicity.

With respect to the quantificational properties of location verbs, note that in the representation of (39) the Place is identified with an abstract INSIDE preposition. We showed in section 4 that prepositions like inside (in contrast with prepositions like in) allow degree modification with certain ground complements. Under the assumption, pointed out in section 4, that degree modifiers can take scope immediately over elements at the subword level (von Stechow 1995; 1996; Bosque \& Masullo 1998), the analysis in (39) predicts that a degree modifier merged on top of Place can exert degree quantification over an inside-type location:

(40) En-terrar massa els bulbs.

in-earth.INF too_much the bulbs

'Bury the bulbs too deep.'

[vP v [DP els bulbs] [PathP Path [PlaceP [QP massa] [PlaceP [DP els bulbst

[Place' Place (= INSIDE) $\sqrt{\text { TERR}]]]]] ~}$ 


\subsection{Locatum verbs as involving a predicative of preposition}

In section 3 it was shown that locatum verbs could be either telic or atelic, the inner-aspectual interpretation depending pretty much on the construal of the embedded root as a bounded entity or an unbounded substance or plurality of entities. This means that the structure involved in these predicates does not determine telicity, and, specifically within the current framework, that it does not correspond to a Path-Place configuration as that proposed for location verbs. Still, we believe that these verbs do involve a prepositional projection. Theory-internal reasons compel us to reach this conclusion. Indeed, within a halekeyserian approach to argument structure, only direct objects denoting effected objects and, according to Volpe's (2004) extension, consumed objects, are considered to be directly selected as complements by the verbal head (see also Mateu 2002):

(41) a. She slept the sleep of the just.

b. He laughed his last laugh.

c. He danced a jig.

(Hale \& Keyser 2002, 71)

d. I eat sashimi.

(Volpe 2004, 12)

[V N (=dream/laugh/jig/sashimi)]

In the case of locatum verbs, it is clearly not the case that the direct object is interpreted as one of the above. Having this into account, we claim that locatum verbs involve a preposition of predicative nature, akin to of. This is shown in the next analysis of the locatum verb envinagrar 'season with vinegar':

(42) En-vinagrar l'amanida.

in-vinegar.INF the $=$ salad

(locatum interpretation)

'To season the salad with vinegar.'

[vP v [oFP [DP l'amanida] OF $^{\prime}$ OF $\sqrt{\text { VINAGR }]]]}$

$\approx$ 'To cause the salad to be vinegar-like.'

There is overt evidence that an of-like preposition is involved in locatum verbs. First, these verbs appear with PPs headed by de 'of' specifying the kind of substance or object involved in the event and subspecified by the verbal root: ${ }^{6}$

\footnotetext{
${ }^{6}$ See similar facts in French in Labelle (2000).
} 
(43) La Jana ha em-polvorat els pastissos de sucre fi. the Jana has in-powder.PTCP the cakes of sugar fine 'Jana has sprinkled caster sugar on the cakes.'

(44) El camp ha quedat minat de mines antipersones. the field has remained mined of mines antipersonnel 'The field has been seeded with antipersonnel mines.'

(45) L'Elna s'ha em-pastifat la cara de maquillatge. the $=$ Elna $\mathrm{REFL}=$ has in-paste.PTCP the face of makeup 'Elna has smeared her face with makeup.'

This de-PP is reminiscent of the one emerging in the change-of-state variant of the locative alternation (Rosselló 2008): ${ }^{7}$

(46) a. La Maria ha carregat el camió de pomes. the Maria has loaded the truck of apples 'Maria has loaded the truck with apples.'

b. La Maria ha carregat pomes al camió. the Maria has loaded apples at=the truck 'Maria has loaded apples into the truck.'

Interestingly, outside of Catalan but within Romance, north-western dialects of European Spanish offer overt evidence of the use of the de preposition in the expression of the specification of the substance involved in a change-of-location event with a light verb like poner(se) 'put' (47). This de-PP also appears in non-dynamic predicates headed by the light verbs tener 'have' (48) or estar 'be in a the state' (49):

(47) Haciendo las magdalenas, Rebeca se ha puesto making the muffins Rebeca REFL has put

las manos de aceite.

the hands of oil

'While baking the muffins, Rebeca has got her hands smeared with oil.'

(48) Rebeca tiene las manos de aceite.

Rebeca has the hands of oil

'Rebeca's hands are smeared with oil.'

${ }^{7}$ In fact, Labelle $(1992,29)$ considers an alternating verb like charger 'load' as being a denominal, locatum verb involving an abstract noun charge 'load'. 
(49) Sus manos están de aceite.

her hands are of oil

'Her hands are smeared with oil.'

Since locatum verbs are not endowed with a Path-Place configuration, they are not specified to be telic. In fact, the predicative preposition involved in these predicates is claimed to be orthogonal to telicity. Thus, a locatum verb like minar can be compatible with both readings, depending on the construal of the root as denoting a bounded or an unbounded entity. In the telic reading we interpret that the field has ended up being completely mined. In the atelic reading there is no concrete amount of mines implied:

(50) Els soldats minaren el camp en/durant una hora.

the soldiers mined the field in/for one hour

The presence of a preposition of predicative, and not locative nature, in locatum verbs makes predictions also with respect of the interpretation of verbal quantification. In particular, a quantificational adjunct merged on top of the projection of the predicative preposition quantifies the degree of the property attained by the entity denoted by the direct internal argument:

(51) En-vinagrar molt l'amanida.

in-vinegar.INF a_lot the $=$ salad

'To season the salad with a lot of vinegar.'

[vP v [ofP [QP molt] [ofP [DP l'amanida][ OF' $^{\prime}$ OF $\sqrt{\text { VINAGR}]]]] ~}$

The difference in the abstract prepositions involved in location and locatum verbs explains the contrast in the interpretation of degree modifiers. This contrast is also manifested with overt predicative and locative prepositions:

(52) a. Ser molt del poble.

be.INF a_lot of=the village

'To behave like a typical person of the village.'

b. Ser molt endins del poble.

be.INF a_lot into of=the village

'To be deep into the village.'

In the first example, de enables a predicative interpretation of the nominal el poble 'the village' and the degree modifier quantifies over this predicate. The predicate can be applied, for example, to a person that has attitudes typical of this particular village. In the second example, molt quantifies over 
the projective preposition endins de 'into', so it measures the extension of an unbounded path leading into the village.

Locatum verbs behave, as far as inner aspect and quantification is concerned, in a way similar to unergative verbs and degree achievements (DAs). This is expected under the assumption that these verbs also do not involve a Path-Place configuration imposing the semantics of a transition. Rather, they can be claimed to involve a configuration that is vague as far as inner aspect and degree quantification is concerned. In section 5.1 we have already made reference to unergative verbs within a discussion of birthing verbs like foal. In predicates headed by these verbs telicity emerges not from properties of the configuration, but of the contextual construal of the root. This explains why certain unergative verbs, like verbs of emission of substance, are inner-aspectually bivalent (see Harley 2005, 48 , footnote 3$)$ :

(53) Bill peed in/for 3 minutes.

The telicity and atelicity of this predicate arguably depends on the fact that the amount of urine is construed as bounded or unbounded, as the context might require. As locatum verbs, unergative verbs also admit i-quantification:

(54) La Jana ha pixat molt. the Jana has peed a_lot

With respect to DAs, such as darken, lengthen, cool, etc., these verbs have two interpretations, one that is telic and can be paraphrased as 'become A' (A being the base adjectival root) and one that is atelic and that can be paraphrased as 'become A-er'. ${ }^{8}$ Thus, to cool can be interpreted as a bounded change of state ('become cool') or as a gradual and unbounded change of state ('become cooler'). This is shown in the classical example by Dowty (1979):

(55) The soup cooled in/for an hour.

Hay et al. (1999) claim that DAs are in fact lexically unambiguous, contrary to the classical theory of gradable deadjectival verbs (Abusch 1986; Declerck 1979; Bertinetto \& Squartini 1995), which proposes that the two

\footnotetext{
${ }^{8}$ As a matter of fact, Dowty (1979) qualified as degree achievements only a subset of the group of verbs standardly identified with this label. See qualifications and relevant discussion in Kearns (2007).
} 
different interpretations of DAs correspond to two different lexical representations, one that yields a bounded change-of-state interpretation or an interpretation of unbounded change. Hay et al. (1999) criticize this proposal and claim that these verbs simply provide an unbounded scale the end-point of which is determined through contextual factors. Their erratic telic/atelic character is derived from how the degree of change implicit in the semantics of the verb is pragmatically construed: as either unbounded, yielding an atelic predicate, or bounded, yielding a telic predicate.

We find an interesting similarity between DAs, as envisioned by Hay et al. (1999), and locatum verbs, as analysed here. In both cases the representation of the verb is claimed to be vague as to boundedness, and the corresponding telic or atelic interpretation depends on contextual factors. A further similarity between DAs and locatum verbs is the licensing of i-quantification. Thus, Bosque \& Masullo $(1998,21)$ provide evidence that a DA like ensanchar 'widen' readily accepts this kind of degree modification:

(56) Hay que ensanchar más la sala.

there_is that widen.INF more the room

'The room must be made wider.'

The different readings that locative verbs show with respect to i-quantification depend on the inner structure of these predicates. While location verbs involve a Path-Place structure below v, locatum verbs involve a predicative structure. As shown before, degree modification of a predicate is affected by the (un)bounded construal of the root: in this sense degree modification of locatum verbs is alike to degree modification of degree achievements. For location verbs, a Path-Place configuration is under the scope of the degree modifier. Thus, i-quantification can only modify locations. The i-quantification and aspectual interpretation are related in locatum verbs because both depend on the (un)bounded interpretation of the embedded predicate. By contrast, i-quantification and aspectual interpretation are orthogonal in location verbs because aspect is structurally determined by the embedded Path-Place configuration, and does not depend on the (un)bounded interpretation of the embedded root.

Let us finally deal with the fact, pointed out in section 3 , that some verbs like envinagrar show an ambiguous interpretation: they can be understood as location verbs or as locatum verbs. As a matter of fact, from a neo-constructionist perspective we expect roots to associate freely with different structures. In the case of envinagrar, for instance, the root $\sqrt{\text { VINAGR }}$ 
may appear in a structure yielding a locatum interpretation, as in (42), or in a structure yielding a location interpretation, as in the next example:

(57) En-vinagrar els cogombres.

(location interpretation)

in-vinegar.INF the cucumbers

'To put the cucumbers in vinegar.'

[vP v [PathP [DP els cogombres] [Path' Path [PlaceP [DP els

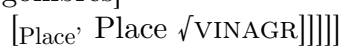

\section{Conclusions}

This work has provided arguments in favour of a non-uniform analysis of locative verbs. Thus, we have supported the idea that under the label of locative verbs we find two verbal classes, location and locatum verbs, that have different syntactic and semantic properties (Labelle 1992; Hale \& Keyser 1997 and subsequent work; MacDonald 2008).

Location verbs are always telic predicates irrespective of the (un-) bounded interpretation of the embedded root. On the contrary, the aspectual interpretation of locatum verbs is calculated contextually, from the (un)bounded construal of the embedded root. This empirical finding has provided arguments to distinguish (at least) two different sources for telicity: one configurational and one that arises from world-knowledge and context. Our claim thus weakens Harley's (2005) generalization that aspect in denominal verbs is always affected by the (un)boundedness of the root. In our approach this is true only if telicity is not structural, supporting the distinction endorsed by Mateu (2002) or Borer (2005), among many others, between configurational and encyclopaedic/conceptual semantics.

We have also provided new evidence for the location/locatum distinction based on their behaviour with respect to i-quantification. While locatum verbs admit i-quantification taking scope over a predicative head, location verbs allow a type of i-quantification which is understood as modifying an embedded location of projective semantics.

\section{Acknowledgements}

The first author acknowledges the funding of grant SFRH/BPD/90892/2012 (Fundação para a Ciência e a Tecnologia, Ministério da Educação e Ciência, Portugal). The second author acknowledges the funding of project FFI2011-29440-C03-3 (Ministerio de Economía y Competitividad, Spain) and 2014SGR-1013 (Agència de Gestió d'Ajuts Universitaris i de Recerca, Generalitat de Catalunya). We are grateful to Jaume Mateu and to two anonymous reviewers, whose comments have greatly improved the quality of this work. All errors are of course only attributable to us. 


\section{References}

Abusch, Dorit. 1986. Verbs of change, causation, and time Report CSLI-86-50. Stanford, CA: CSLI.

Acedo-Matellán, Víctor. 2006. Una aproximació sintàctica als verbs prefixats en català. Estudios Catalanes 4. 41-78.

Acedo-Matellán, Víctor. 2010. Argument structure and the syntax-morphology interface. A case study in Latin and other languages. Doctoral dissertation. Universitat de Barcelona.

Bassani, Indaiá. 2012. Morphology-syntax interface: The relation between prefixes of Brazilian Portuguese and argument structure. University of Pennsylvania Working Papers in Linguistics 18. 11-20.

Bertinetto, Pier Marco and Mario Squartini. 1995. An attempt at defining the class of 'Gradual Completion' verbs. In P. M. Bertinetto, V. Bianchi, J. Higginbotham and M. Squartini (eds.) Temporal reference aspect and actionality. Vol. 1: Semantic and syntactic perspectives. Torino: Rosenberg and Sellier. 11-26.

Binnick, Robert. 1969. Studies in the derivation of predicative structures. Doctoral dissertation. University of Chicago.

Borer, Hagit. 2005. Structuring sense II: The normal course of events. Oxford: Oxford University Press.

Bosque, Ignacio and Pascual J. Masullo. 1998. On verbal quantification in Spanish. In O. Fullana and F. Roca (eds.) Studies on the syntax of central Romance languages. Girona: Universitat de Girona. 9-63.

Clark, Eve V. and Herbert H. Clark. 1979. When nouns surface as verbs. Language 55. $767-811$.

Declerck, Renaat. 1979. Aspect and the bounded/unbounded (telic/atelic) distinction. Linguistics 17. 761-794.

Di Sciullo, Anna Maria. 1996. Prefixes and suffixes. In C. C. Parodi, M. S. Quicoli and M. L. Zubizarreta (eds.) Aspects of Romance linguistics. Revised versions of papers presented at the XXIV Linguistic Symposium on Romance Languages, held in Los Angeles, California, March 10-13, 1994. Washington, DC: Georgetown University Press. 177-194.

Dowty, David R. 1979. Word meaning and Montague grammar: The semantics of verbs and times in generative syntax and in Montague's PTQ. Dordrecht: Reidel.

Folli, Raffaella and Heidi Harley. 2006. On the licensing of causatives of directed motion: Waltzing Matilda all over. Studia Linguistica 60. 121-155.

Gallego, Ángel and Aritz Irurtzun. 2010. Verbal quantification in Romance revisited: An l-syntax approach. Paper presented at the Workshop on Verb Meaning, Event Semantics and Argument Structure, December 2-3, 2010, Universitat Autònoma de Barcelona, Bellaterra.

Hale, Kenneth. 1986. Notes on world view and semantic categories: Some Warlpiri examples. In P. Muysken and H. van Riemsdijk (eds.) Features and projections. Dodrecht: Foris. 233-254.

Hale, Kenneth and Samuel Jay Keyser. 1991. On the syntax of argument structure (Lexicon Project Working Paper 34). Cambridge, MA: MIT Press. 
Hale, Kenneth and Samuel Jay Keyser. 1993a. On argument structure and the lexical expression of syntactic relations. In Hale \& Keyser (1993b, 53-109).

Hale, Kenneth and Samuel Jay Keyser (eds.). 1993b. The view from building 20. Essays in linguistics in honor of Sylvain Bromberger. Cambridge, MA: MIT Press.

Hale, Kenneth and Samuel Jay Keyser. 1994a. Constraints on argument structure. In B. Lust, M. Suñer and J. Whitman (eds.) Syntactic theory and first language acquisition: Cross-linguistic Perspectives. Vol. 1: Heads, projections and learnability. Hillsdale, NJ: Lawrence Earlbaum. 53-71.

Hale, Kenneth and Samuel Jay Keyser. 1994b. On the complex nature of simple predicators. Manuscript. MIT.

Hale, Kenneth and Samuel Jay Keyser. 1997. The limits of argument structure. In A. M. Mendikoetxea and M. Uribe-Etxebarria (eds.) Theoretical issues at the morphology-syntax interface. Bilbao/Donostia-San Sebastián: Universidad del País Vasco and Diputación Foral de Gipuzkoa. 203-230.

Hale, Kenneth and Samuel Jay Keyser. 2002. Prolegomenon to a theory of argument structure. Cambridge, MA: MIT Press.

Halle, Morris and Alec Marantz. 1993. Distributed morphology and the pieces of inflection. In Hale \& Keyser (1993b, 111-176).

Harley, Heidi. 2005. How do verbs get their names? Denominal verbs, manner incorporation and the ontology of verb roots in English. In N. Erteschik-Shir and T. Rapoport (eds.) The syntax of aspect. Oxford: Oxford University Press. 42-64.

Harley, Heidi and Rolf Noyer. 1999. Distributed morphology. GLOT International 4. 3-9.

Hay, Jennifer, Christopher Kennedy and Beth Levin. 1999. Scalar structure underlies telicity in 'Degree Achievements'. In T. Mathews and D. Strolovitch (eds.) Semantics and linguistic theory (SALT) IX. Ithaca, NY: CLC Publications, Cornell University. 127-44.

Jackendoff, Ray. 1990. Semantic structures. Cambridge, MA: MIT Press.

Kearns, Kate. 2007. Telic senses of deadjectival verbs. Lingua 117. 26-66.

Kiparsky, Paul. 1997. Remarks on denominal verbs. In A. Alsina, J. Bresnan and P. Sells (eds.) Complex predicates. Stanford: CSLI Publications. 473-499.

Kiparsky, Paul. 1998. Partitive case and aspect. In W. Greuder and M. Butt (eds.) The projection of arguments. Stanford: CSLI Publications. 265-307.

Kopecka, Anetta. 2006. The semantic structure of motion verbs in French. In M. Hickmann and S. Robert (eds.) Space in languages: Linguistic systems and cognitive categories. Amsterdam \& Philadelphia: John Benjamins. 83-101.

Kratzer, Angelika. 2000. Building statives. Proceedings of the Annual Meeting of the Berkeley Linguistics Society 26. 385-399.

Krifka, Manfred. 1989. Nominal reference, temporal constitution and quantification in event semantics. In R. Bartsch, J. van Benthem and P. van Emde Boas (eds.) Semantics and contextual expression. Dordrecht: Foris. 75-115.

Krifka, Manfred. 1992. Thematic relations as links between nominal reference and temporal constitution. In I. A. Sag and A. Szabolcsi (eds.) Lexical matters: From cognitive structures to syntactic structures. Stanford, CA: CSLI Publications. 29-53.

Krifka, Manfred. 1998. The origins of telicity. In S. Rothstein (ed.) Events and grammar. Dordrecht: Kluwer. 187-235. 
Labelle, Marie. 2000. The semantic representation of denominal verbs. In P. Coopmans, M. Everaert and J. Grimshaw (eds.) Lexical specification and insertion. Amsterdam \& Philadelphia: John Benjamins. 215-240.

MacDonald, Jonathan. 2008. The syntax of inner aspect. A Minimalist perspective. Amsterdam \& Philadelphia: John Benjamins.

Marantz, Alec. 1997. No escape from syntax: Don't try morphological analysis in the privacy of your own lexicon. University of Pennsylvania Working Papers in Linguistics 4. 201-225.

Marantz, Alec. 2013. Verbal argument structure: Events and participants. Lingua 130. $152-168$.

Mateu, Jaume. 2001. On the relational semantics of transitive denominal verbs. In M. L. Jungl, O. F. Soriano and M. V. E. Vidal (eds.) Current issues in generative grammar. Alcalá de Henares: Servicio de Publicaciones de la Universidad de Alcalá. 143-164.

Mateu, Jaume. 2002. Argument structure. Relational construal at the syntax-semantics interface. Doctoral dissertation. Universitat Autònoma de Barcelona, Bellaterra. http://seneca.uab.cat/clt/publicacions/tesis/index.html

Mateu, Jaume. 2008. Argument structure and denominal verbs. Paper presented at the Workshop on Bare Singulars, Argument Structure, and Their Interpretation, December 11-12, 2008, Universitat Autònoma de Barcelona, Bellaterra.

Pinker, Steven. 1989. Learnibility and cognition: The acquisition of argument structure. Cambridge, MA: MIT Press.

Real-Puigdollers, Cristina. 2013. Lexicalization by phase: The role of prepositions in argument structure and its cross-linguistic variation. Doctoral dissertation. Universitat Autònoma de Barcelona, Bellaterra.

Rosselló, Joana. 2008. El SV I: Verb i arguments verbals. In J. Solà, M. R. Lloret, J. Mascaró and M. P. Saldany (eds.) Gramàtica del Català Contemporani. Vol. 2: Sintaxi. Barcelona: Empúries. 1853-1949.

Stechow, Arnim von. 1995. Lexical decomposition in syntax. In U. Egli, P. E. Pause, C. Schwarze, A. von Stechow and G. Wienold (eds.) Lexical knowledge in the organization of language. Amsterdam \& Philadelphia: John Benjamins. 81-177.

Stechow, Arnim von. 1996. The different readings of wieder 'again': A structural account. Journal of Semantics 13. 87-138.

Tenny, Carol L. 1989. The aspectual interface hypothesis. Lexicon Project Working Papers 31. $2-47$.

Tenny, Carol L. 1994. Aspectual roles and the syntax-semantics interface. (Studies in Linguistics and Philosophy 52). Dordrecht: Kluwer.

Verkuyl, Henk J. 1972. On the compositional nature of the aspects. Dordrecht: Reidel.

Volpe, Mark. 2004. Affected object unergatives. Snippets 8. 12-13.

Zwarts, Joost. 1997. Vectors as relative positions: A compositional semantics of modified PPs. Journal of Semantics 14. 57-86.

Zwarts, Joost and Yoad Winter. 2000. Vector space semantics: A model-theoretic analysis of locative prepositions. Journal of Logic, Language and Information 9. 169-211. 